\title{
The determinants of Finance Companies' profitability in Sri Lanka
}

\author{
敝 \\ MAHADE WAN SUUIIHAMAR
}

A research submitted to the University of Sri Jayewardenepura in partial fulfillment of the requirements for the Degree of Master of Business Administration (Finance) 
The work described in this research was carried out by me under the supervision of Prof. W.M.A.Bandara and a report on this has not been submitted in whole or in part to any university or any other institution for another Degree or Diploma.

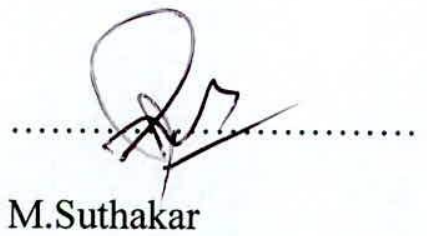

\section{$20 / 5 / 2013$}

Date 
I certify that the above statement made by the candidate is true and that this research is suitable for submission to the University for the purpose of evaluation.

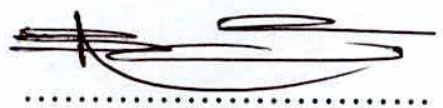

Prof. W.M.A.Bandara

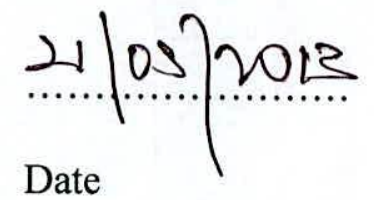




\section{CHAPTER - ONE}

1. INTRODUCTION $1-13$

1.1 Overview of Sri Lankan financial institutions ...............................................

1.2 Overview of Sri Lankan finance companies ...................................................2

1.3 Recent developments in the finance company sector .....................................5

1.3.1 Introduction to the Finance Business Act No. 42 of 2011 ................... 5

1.3.2 Introduction to Deposit insurance scheme ........................................... 6

1.3.3 Compulsory listing in CSE ............................................................ 7

1.3.4 Enhancement of minimum Core Capital ..............................................

1.3.5 Corporate governance to LFCs ........................................................ 7

1.3.6 Appointment of External Auditors ......................................................8

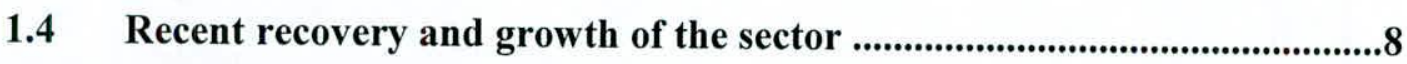

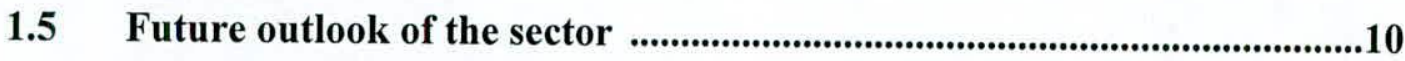

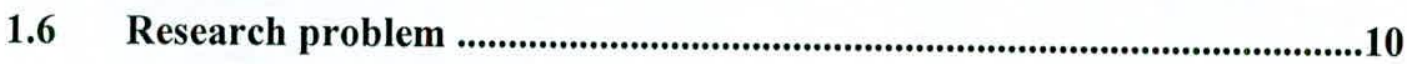

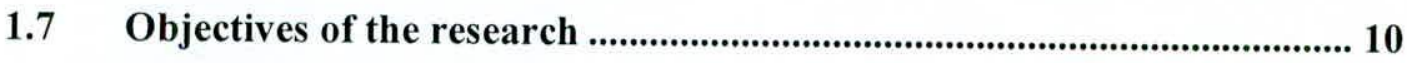

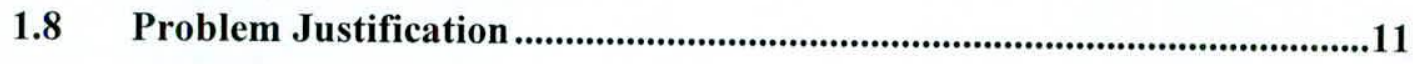

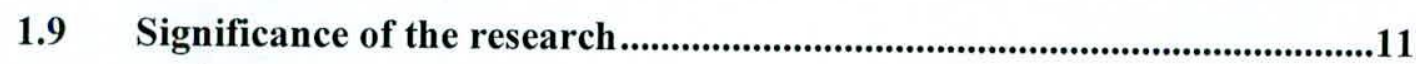

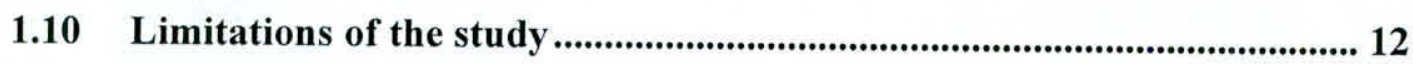

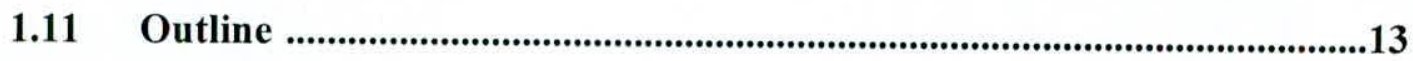

\section{CHAPTER - TWO}

2 LITERATURE REVIEW ......................................................................... 14 - 44

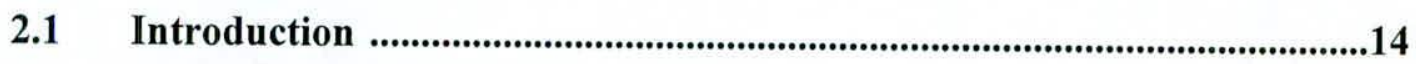

2.2 Internal / firm specific determinants ..........................................................15 


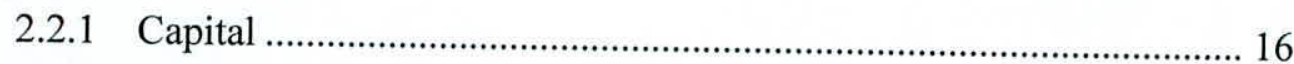

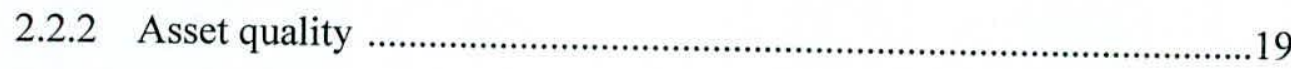

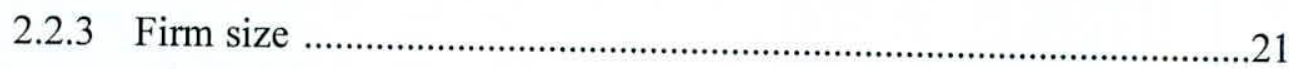

2.2.4 Expense Management .....................................................................22

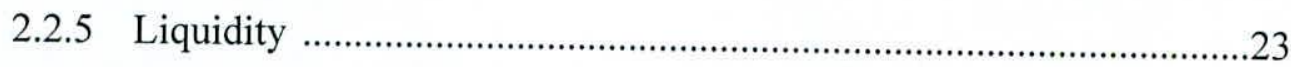

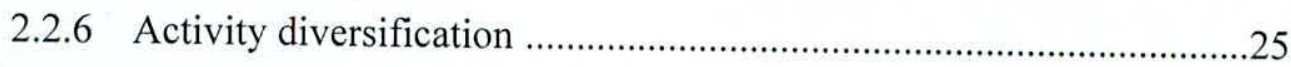

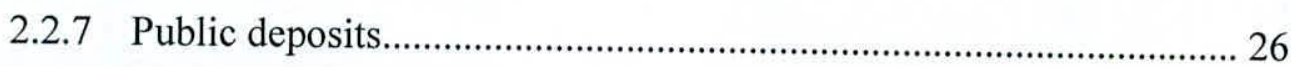

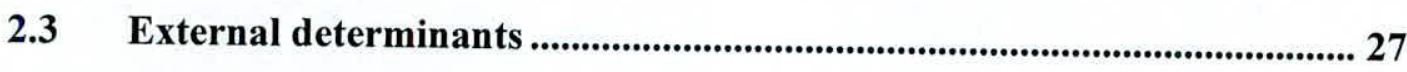

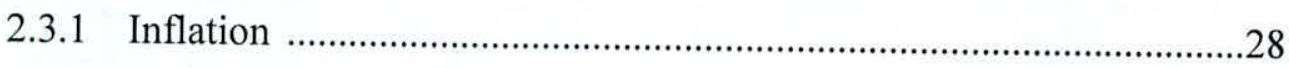

2.3.2 Economic Growth ............................................................................ 30

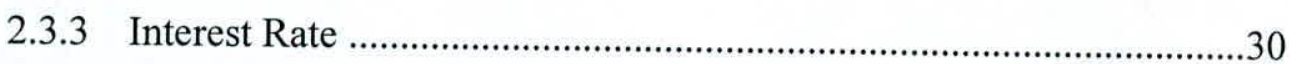

2.4 Impact of Management Quality, Corporate Governance and Risk Management on Profitability ......................................................................32

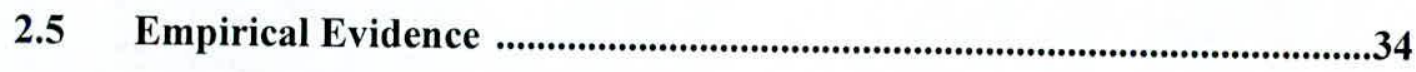

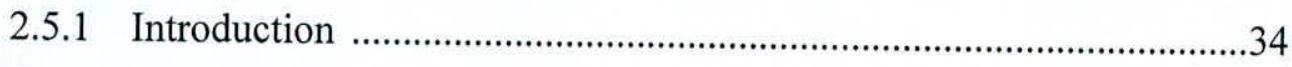

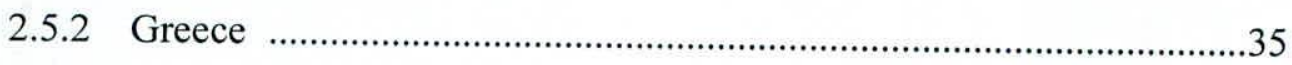

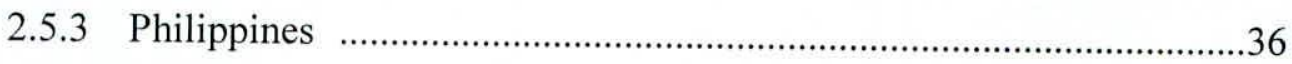

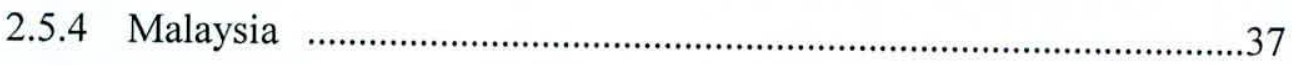

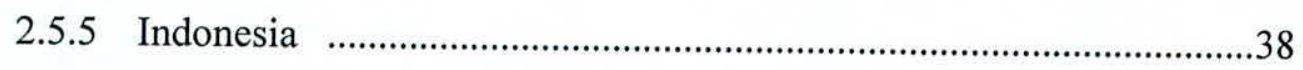

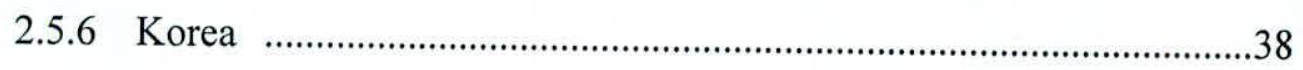

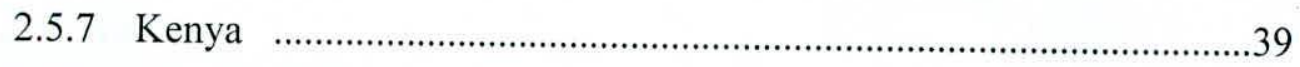

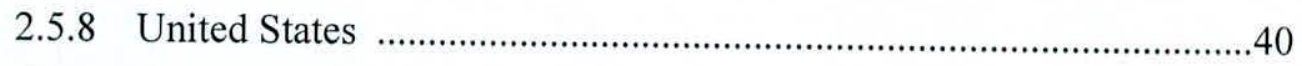

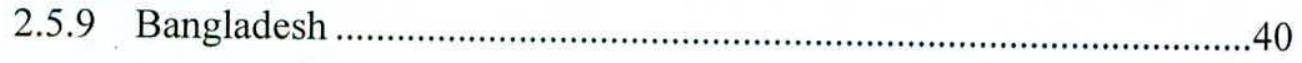

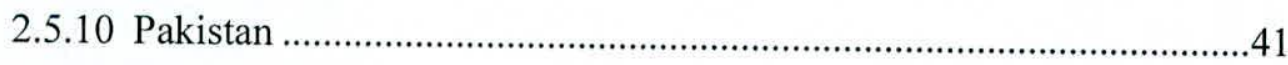

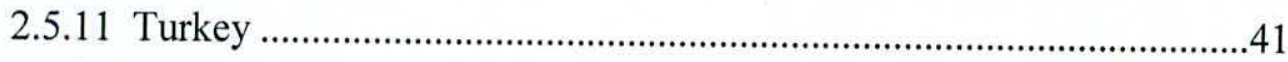




\section{CHAPTER - THREE}

3 METHODOLOGY 45 - 61

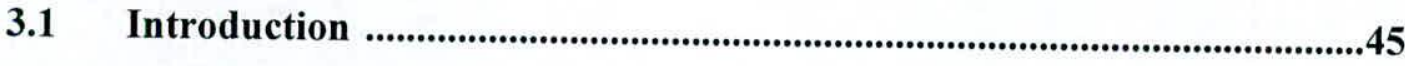

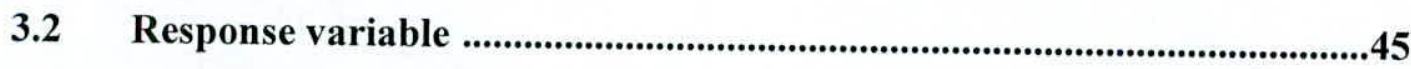

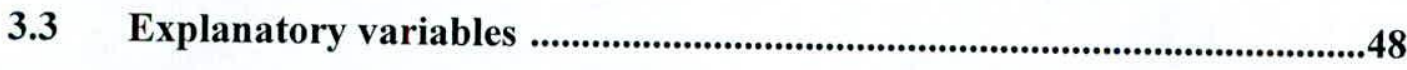

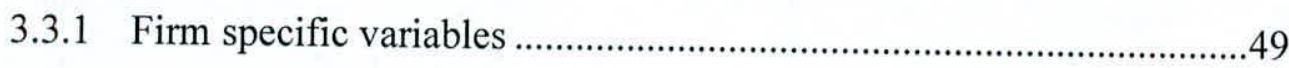

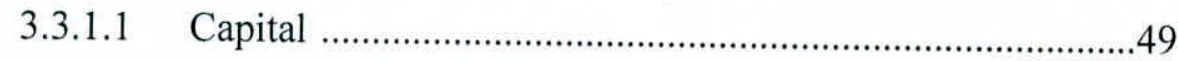

3.3.1.2 Asset quality .................................................................49

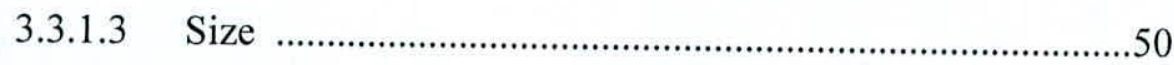

3.3.1.4 Expense management ......................................................50

3.3.1.5 Asset Composition ..............................................................51

3.3.1.6 Liquidity …....................................................................51

3.3.1.7 Public Deposits ..................................................................52

3.3.1.8 Non-interest income …...................................................52

3.3.2 External / Macroeconomic variables ....................................................53

3.3.2.1 Interest rate …..............................................................53

3.3.2.2 Economic Growth .............................................................53

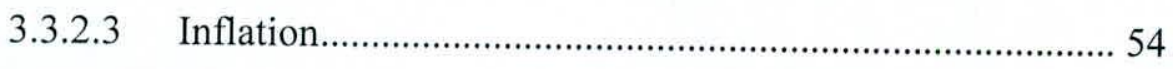

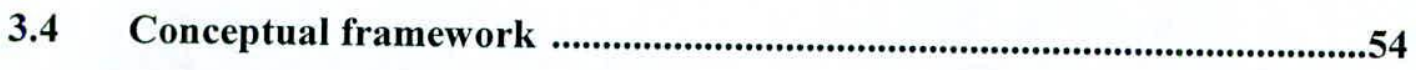

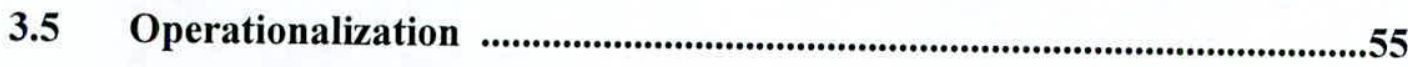

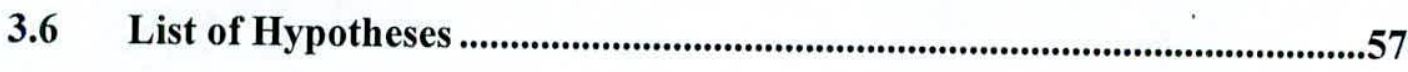




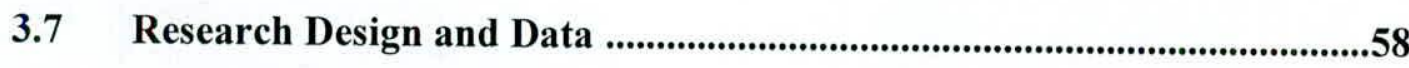

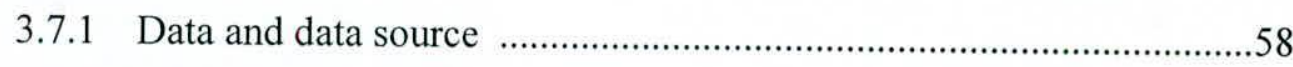

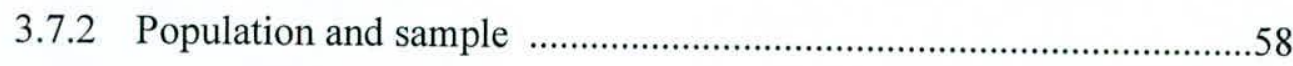

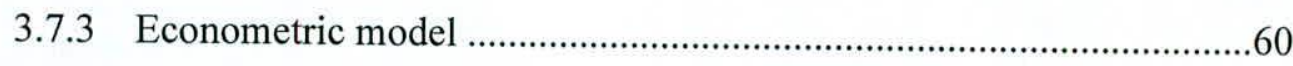

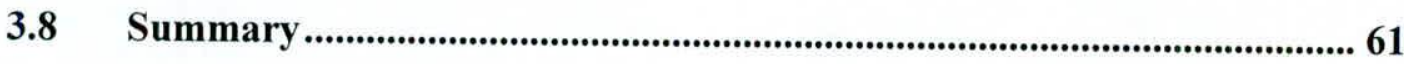

\section{CHAPTER - FOUR}

4 DATA ANALYSIS $62-88$

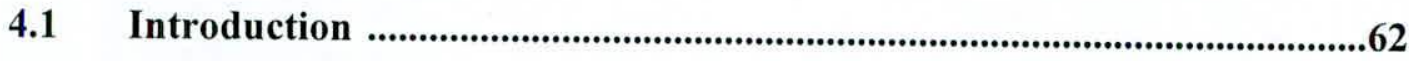

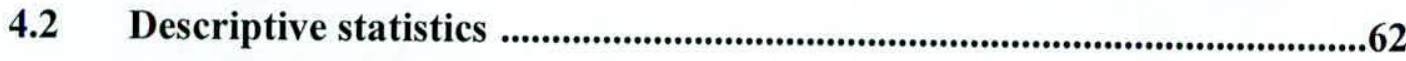

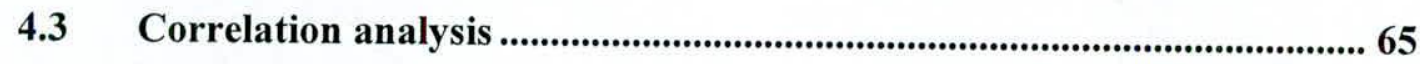

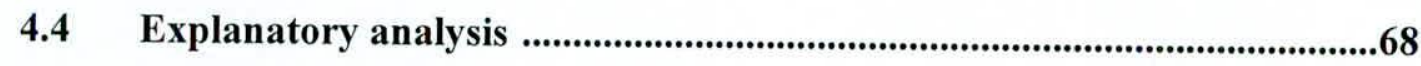

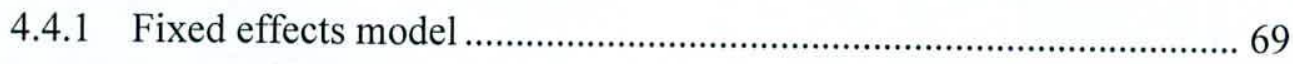

4.4.2 Random effects model ................................................................... 70

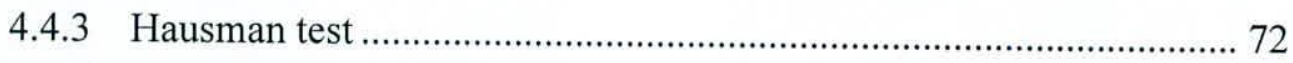

4.4.4 Heteroskedasticity ......................................................................... 73

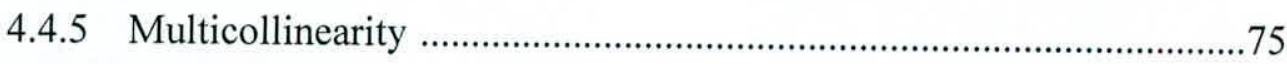

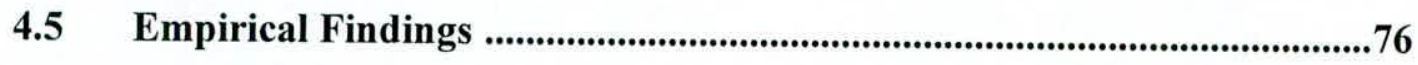

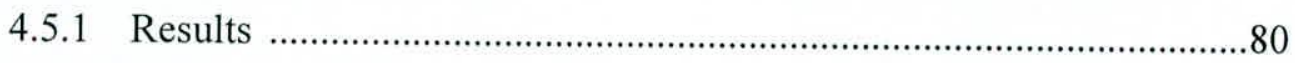

4.6 Trend Analysis of LFC sector profitability and other factors ..................84

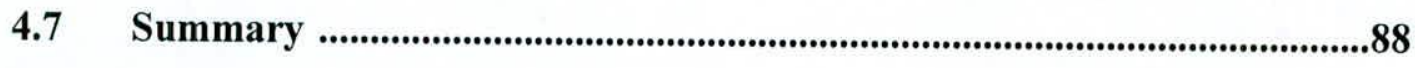

\section{CHAPTER - FIVE}

5 DISCUSSION $89-96$

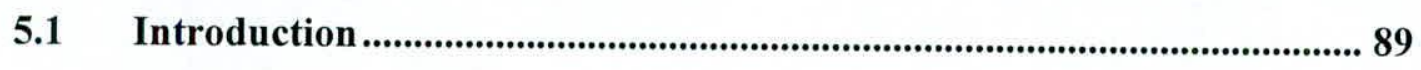




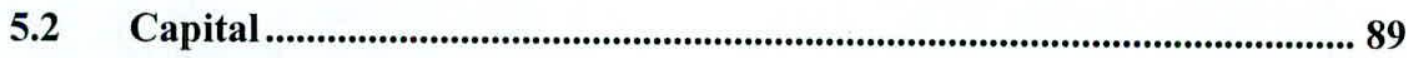

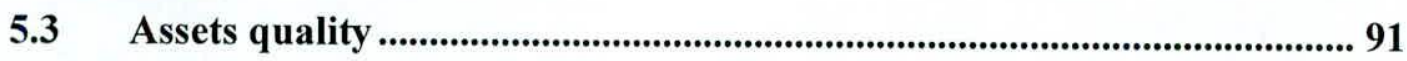

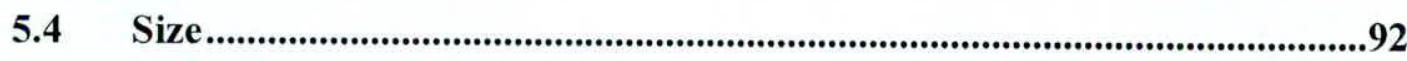

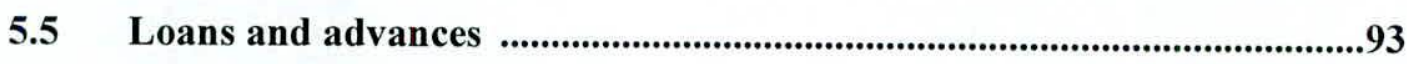

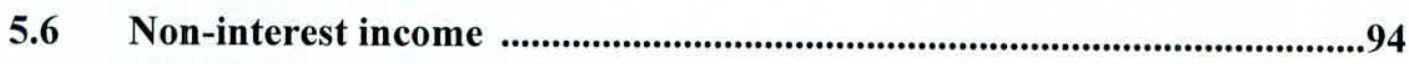

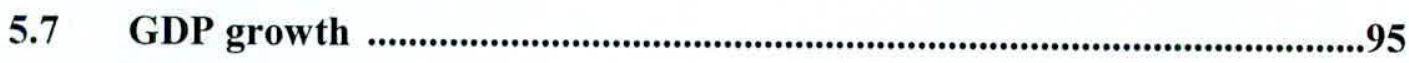

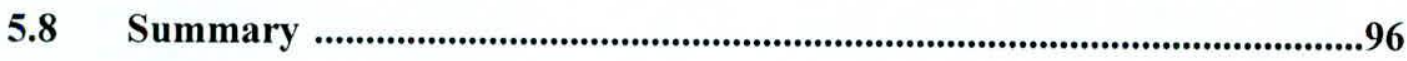

\section{CHAPTER - SIX}

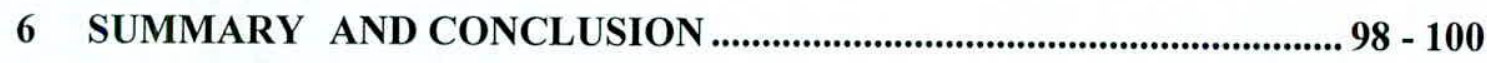

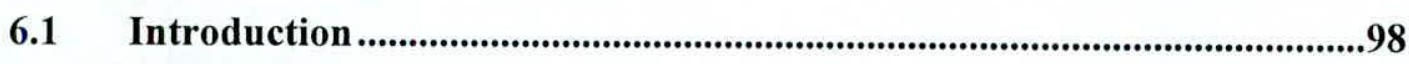

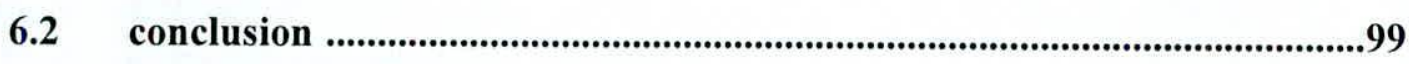

6.3 Recommendations for future research .................................................100

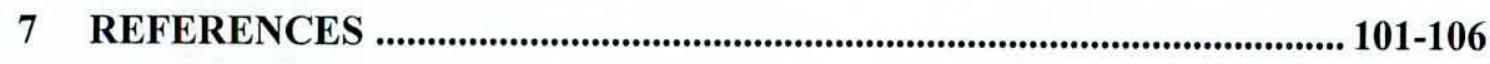

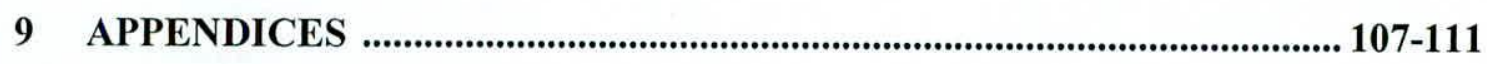




\section{List of Tables}

1. Table 1.1: List of Licensed Finance Companies listed in the CSE.................4

2. Table 1.2: List of Finance Companies not listed in the CSE ...........................

3. Table 3.1: Definition, notation and expected effects of explanatory variables .56

4. Table 3.2: List of Hypotheses ..........................................................................5

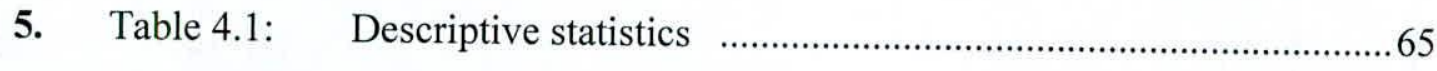

6. Table 4.2: Correlation matrix ...........................................................................67

7. Table 4.3: Results of the Fixed Effects model ................................................

8. Table 4.4: Results of the Random Effects Model ...........................................71

9. Table 4.5: Results of the Hausman Test...........................................................

10. Table 4.6: Results of Random effects with Robust error term.........................74

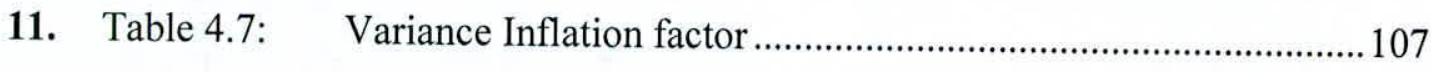

12. Table 4.8: Results under random effects model (all explanatory variables). 77

13. Table 4.9: Results under random effects model (firm specific variables) ....78

14. Table 4.10: Results under random effects model (firm specific variables), under ROE as a proxy for profitability .79 
1. Figure 1.1: Movement of NIM, ROA and NPL of the LFC Sector..................9

2. Figure 1.2: Assets, Public Deposits and Capital growth of LFC sector ...........9

3. Figure 3.1: Conceptual model .........................................................................5

4. Figure 3.2: Population and sample of the research .........................................59

5. Figure 3.3: Size of the LFCs included in the sample ......................................59

6. Figure 4.1: ROA, ROE and NIM movement based on research sample .......84

7. Figure 4.2: ROA and NIM movements based on Macroeconomic

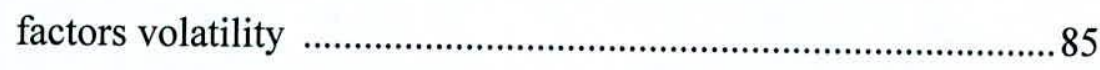

8. Figure 4.3: NPL Movements of LFCs based on Macroeconomic

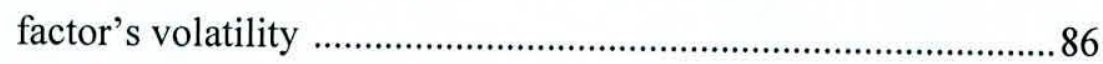

9. Figure 4.4: Movements of composition of funding …….................................8 87

10. Figure 4.5: Movements of composition of Loans and Advances ...................8 87 


\section{ACKNOWLEDGEMENTS}

Pursuing a Master Research in Finance is both an interesting and pleasurable experience. The experiences during the research period are hardships, encouragements and confidence gained from great people's support. My first sincere thanks go to my Professor K.D.Gunawardene, who initiated me to search for a research topic while emphasising the importance of the research work for the MBA degree program. Secondly my special thanks go to my advisor Professor W.M.A.Bandara, who accepted me without any hesitation as his student. His experiences in academic life and industry exposure assisted me throughout my research period. His encouragement and assistance even with his busy schedule, made me feel confident to achieve my objectives. Next I appreciate the advice of Dr. M.H.A. Sisira Kumara, who extended his full support to form the econometric model and to arrive at the outcome of my analysis. I made use of his expert knowledge in econometrics and his art of teaching for a layman. Further I am thankful to the former coordinator Dr. P.D. Nimal, and present coordinator Dr. P.J.Kumarasinghe, both of whom always encourage and guide students to meet with deadlines. I must thank the non academic staffs of the Postgraduate unit for their support during the tenure of my research. Special thanks go out to my family, relatives and friends who supported me during the study by arranging reference lists, formatting, editing and proof reading. My sincere thanks also go to all who supported me in different capacities. Moreover, it is my hope that this research contributes a practical knowledge to the determinants of finance companies' profitability.

Mahadevan Suthakar

Colombo, February 2013. 


\title{
The determinants of Finance Companies' profitability in Sri Lanka
}

\author{
Mahadevan Suthakar \\ MBA Finance (Student) \\ Faculty of Graduates Studies, \\ University of Sri Jayewardenepura.
}

\section{ABSTRACT}

In this study, balanced panel data sets of Sri Lankan Finance Companies were used to investigate the firm specific (endogenous) and macroeconomic (exogenous) determinants of profitability of Finance Companies using the random effects model. For this purpose 130 observations of 26 Finance Companies (out of 43) over the period 2008 - 2012 were included. Return on Assets was considered as a measure for profitability of Finance Companies and Return on Equity was considered as an alternative measure. Capital, Assets Quality, Size, Overhead expenses Management, Composition of loans and advances, Liquidity, Public Deposits and Noninterest income are considered as endogenous factors whereas Interest rate, GDP growth rate and Inflation rate are considered as exogenous factors. The result shows that Capital, Size, Composition of loans and advances, Noninterest income have a positive and significant impact on finance company profitability. However Non performing loans (proxy for asset quality) have a negative and significant impact on profitability. With regard to exogenous variables, GDP growth has significant positive influences on profitability. Based on these findings, this study recommends maintaining healthy capital ratios, concentration on asset quality, improving size with diversified branch networks, investing more on loans and advances and involvement of fee based activities that will enhance the profitability positively. 
Further research on impact of Finance Companies' profitability with Management Quality, Corporate Governance and Risk Management will not only add value to explaining profitability of Finance Companies but also add value to the academic literature.

Keywords: Financial institutions, Sri Lankan Finance companies' profitability, firm specific factors, macroeconomic factors, panel data 


\title{
ABBREVIATIONS
}

\author{
ASPI All Share Price Index \\ BCBS Basel Committee on Bank Supervision \\ CAR Capital Adequacy Ratio \\ CBSL Central Bank of Sri Lanka \\ CCPI Colombo Consumer Price Index \\ CEO Chief Executive Officer \\ COIN Cost to Income Ratio \\ CSE Colombo Stock Exchange \\ DETA Deposits to Total Assets \\ DIS Sri Lanka Deposit Insurance Scheme \\ EQTA Equity to Total Assets \\ EVA Economic Value Added \\ GDP Gross Domestic Product \\ GMM Generalized Method of Moments \\ ICASL Institute of Chartered Accountants of Sri Lanka \\ IMF International Monetary Fund \\ INF Inflation Rate \\ INT Interest Rate \\ IPO Initial Public Offer \\ LATA Loans and Advances to Total Assets \\ LCB Licensed Commercial Bank \\ LFC Licensed Finance Company
}


LSB Licensed Specialized Banks

NBFI Non Bank Financial Institutions

NCBFI Non Commercial Bank Financial Institutions

NIITA Non Interest Income to Total Assets

NIM Net Interest Margin

NPL Non Performing Loans

OLS Ordinary Least Squares

RAROC Risk Adjusted Return on Capital

RFC Registered Finance Company (Now known as LFC)

ROA Return on Assets

ROE Return on Equity

SEC Securities and Exchange Commission of Sri Lanka

SLC Specialized Leasing Company

VAT Value Added Tax

VIF Variance Inflation Factor 